\title{
AN UNDERWATER SPOILER ON A WARSHIP: WHY, WHEN AND HOW?
}

\section{Bruno Bouckaert}

Hull Vane B.V., Nude 46, 6702 DM, Wageningen, The Netherlands; e-mail: b.bouckaert@hullvane.com

\begin{abstract}
There are a lot of energy saving devices for ships on the market, but few have seen wide adoption on naval ships, with one exception: the bulbous bow. The bulbous bow was developed for naval ships in the early $20^{\text {th }}$ century and is now widespread on a variety of ship designs. Many have wondered if the effect of the bulbous bow - reducing the resistance of a ship by reducing the bow wave - could be replicated somehow at the stern — by reducing the stern wave. This is exactly what is done by a novel and patented energy saving device called Hull Vane ${ }^{\circledR}$.

Invented by Dutch hydrodynamicist Dr Peter van Oossanen for an America's Cup sailing yacht in the early $21^{\text {st }}$ century, research over the years has shown that this wing-shaped appendage works best on ships that combine a relatively high displacement with a relatively high top speed requirement - even if most sailing hours are done at half speed. Examples are certain offshore vessels, superyachts, patrol vessels and naval ships. On offshore patrol vessels, the resistance reduction from the Hull Vane ${ }^{\circledR}$ ranges typically from 10 to $20 \%$ over the entire useful speed range.

In this paper, the working principles of the Hull Vane ${ }^{\circledR}$ will be described to give a better understanding of the device. An overview will be given of the work carried out on naval ships and coastguard ships (25 to $142 \mathrm{~m}$ ), based on Computational Fluid Dynamics studies, model tests and full-scale applications. The question 'Why?' will be answered by translating the hydrodynamic effects to concrete capability improvements for naval ships: a lower fuel consumption, a longer range, reduced signature, a higher top speed and improved seakeeping.
\end{abstract}


The question 'When?' will zoom in on whether a Hull Vane ${ }^{\circledR}$ is something to be included in a newbuild or if it is something to be retrofitted to an existing ship. Finally the answer to the question 'How?' will explain the process of either integrating a Hull Vane ${ }^{\circledR}$ in a newbuild project or retrofitting it during a midlife upgrade of an existing ship.

\section{Key words:}

hydrodynamics, naval ships, efficiency, energy saving, seakeeping, capabilities.

Research article

(C) 2018 Bruno Bouckaert This is an open access article licensed under the Creative Commons Attribution-NonCommercial-NoDerivatives 4.0 license (http://creativecommons.org/licenses/by-nc-nd/4.0/) 


\section{INTRODUCTION}

This paper summarises the research work done relevant for naval ships in several studies and full-scale applications. The Hull Vane ${ }^{\circledR}$ looks like an inverted spoiler placed under water, but is basically a patented application of a hydrofoil on ships which are much heavier and slower those where hydrofoils are commonly used (e.g. fast ferries). Rather than lifting the ship out of the water, to reduce wetted surface, the wing is used in a different way to reduce the resistance. There are many different configurations of the Hull Vane ${ }^{\circledR}$, and the actual configuration depends of the ship-specific optimisation, the build costs and the constraints imposed on the location of the Hull Vane ${ }^{\circledR}$. There are TT-shaped Hull Vanes, which feature a straight hydrofoil section and (near) perpendicular vertical struts and U-shaped Hull Vanes, in which the tips are curved upwards to form the struts attached to the hull. The Hull Vane ${ }^{\circledR}$ can be either appended, which means it is located behind the transom, or integrated, which means it is located within the waterline length of the main hull. An endless amount of variations is possible, such as U-shaped with intermediate struts, hydrofoil sections with dihedral and curved-up wingtips. In the fig. 1 and 2 below, two examples of basic configurations are shown.

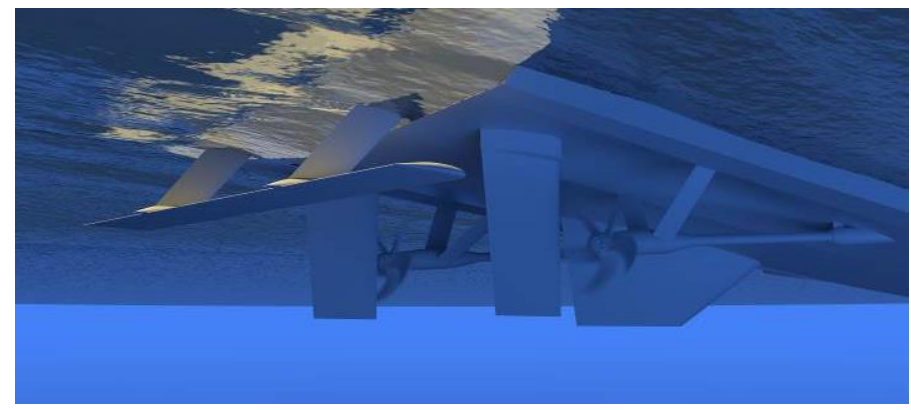

Fig. 1. Typical appended TT-shaped Hull Vane ${ }^{\circledR}[2]$

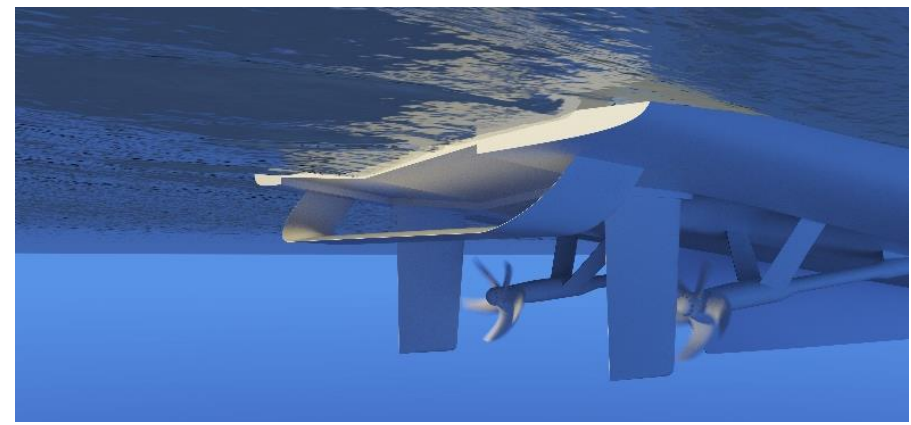

Fig. 2. Typical integrated U-shaped Hull Vane ${ }^{\circledR}[2]$

$3(214) 2018$ 


\section{WORKING PRINCIPLES}

There are four basic effects of the Hull Vane ${ }^{\circledR}$, of which three manifest themselves in all conditions and the fourth only when the ship sails in waves.

1. The hydrofoil generates a forward-angled lift force out of the upward flow under the aftbody of the vessel. The wing generates a drag force and a lift force, which together form the resultant Force HV, as pictured in fig. 3. The horizontal component of this force provides forward thrust, which is transferred to the ship through the struts. The thrust force is represented as Forcex HV in fig. 4.

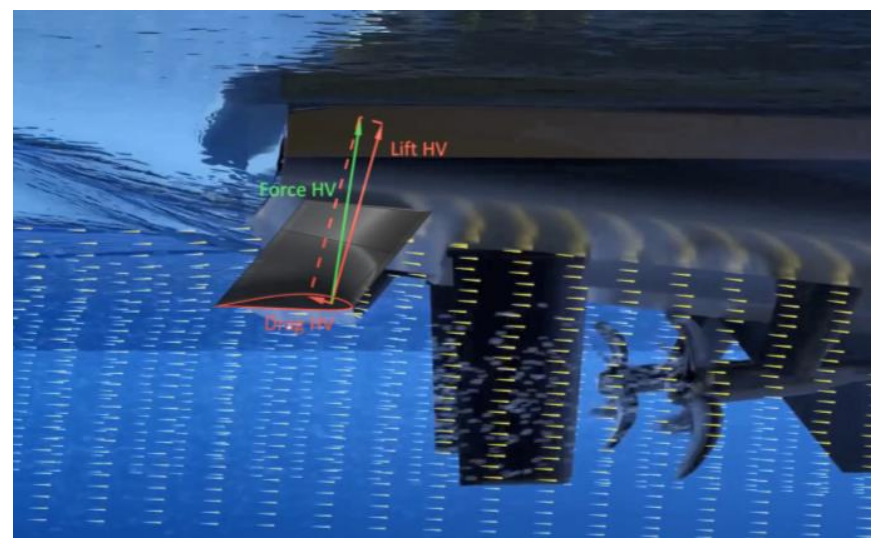

Fig. 3. The wing generates a lift and drag force [7]

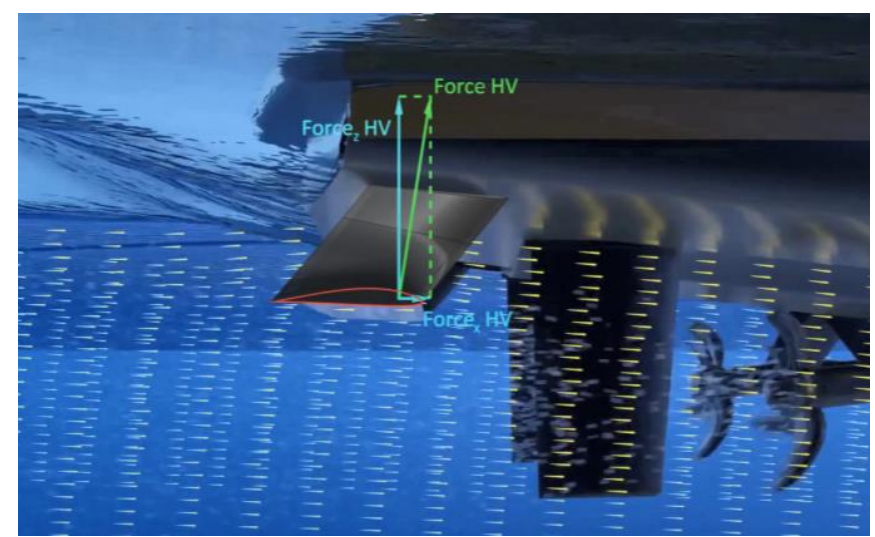

Fig. 4. The resultant is angled forward and has a Fx component [7]

2. The hydrofoil influences the wave pattern by introducing a low-pressure region behind the transom. By reducing the stern wave, the Hull Vane ${ }^{\circledR}$ reduces the wavemaking resistance of the ship. This can be seen in fig. 5 for a $55 \mathrm{~m}$ vessel sailing 
at 20 knots. Essentially all waves generated by a ship are a sign of energy wasted, just like noise is such a sign. Minimising the waves generated reduces the resistance. This is also the basis for the working principle of the bulbous bow.

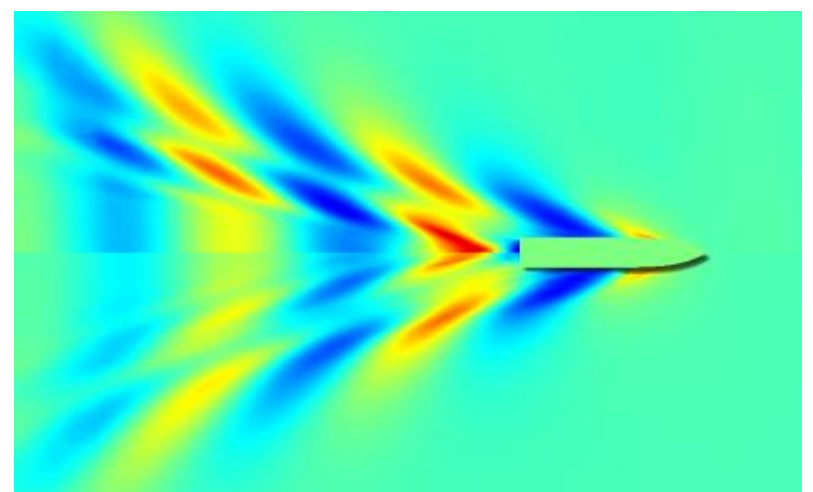

Fig. 5. Wave profile without (upper halve) and with (lower halve) Hull Vane ${ }^{\circledR}$ on 55m FSIV Karina at 20 knots. Indicated in red are wave tops and in blue are wave troughs (elevation compared to neutral water plane) [3]

3. The vertical component of the lift generates a bow-down moment in a more efficient way than trim wedges, stern flaps or interceptors [1]. The Hull Vane $₫$ generates this lift force at a lower (intermediate) speed, and with a lower drag penalty at very low speeds $(\mathrm{Fn}<0.2)$ than stern flaps or trim wedges.

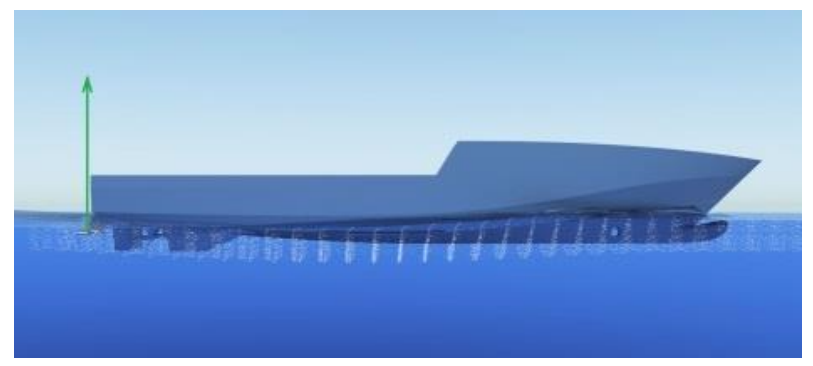

Fig. 6. Trim correction [5]

4. The Hull Vane ${ }^{\circledR}$ dampens the ship motions such as pitching and yawing when sailing in waves, and therefore reduces the added resistance caused by these motions. CFD computations and force measurements during model tests have also shown that additional thrust is generated when the wing moves up and down in a flow (due to pitching). This effect is called the 'pumping effect' and is seen in other hydrofoil applications such as the Pump-a-bike watertoy. 


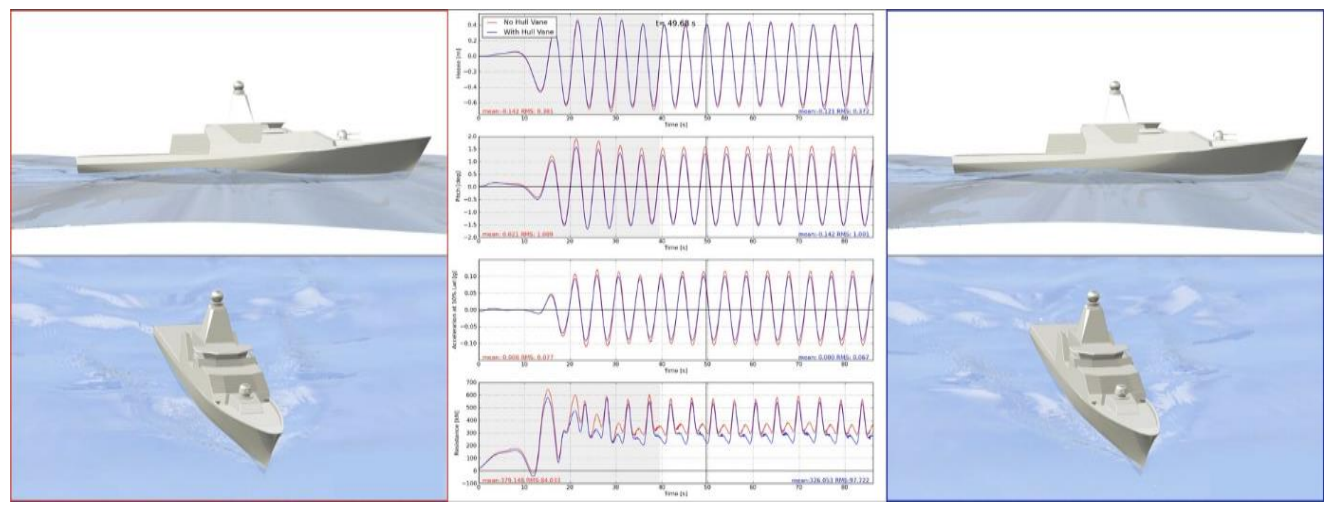

Fig. 7. Pitch damping when sailing in waves, graphs in the middle showing respectively heave, pitch, vertical accelerations at heli-deck and resistance signal versus timesteps [1]

\section{NAVAL CASE STUDIES}

A number of studies have shown that the Hull Vane ${ }^{\circledR}$ is very effective at reducing the resistance of ships which combine a relatively high displacement with a wide range of operating speeds. Naval and coastguard ships are a typical example of this. Examples of such ship types are Offshore Patrol Vessels, Corvettes, Frigates and Destroyers. Based on the performance of similar commercial vessels, good performance can also be expected on Landing Platform Docks, Auxiliary Replenishment Vessels (naval tankers) and Mine Countermeasure Vessels.

A few relevant examples are given below, and the results briefly described for each:

1. MV Karina, fast supply vessel/offshore patrol vessel

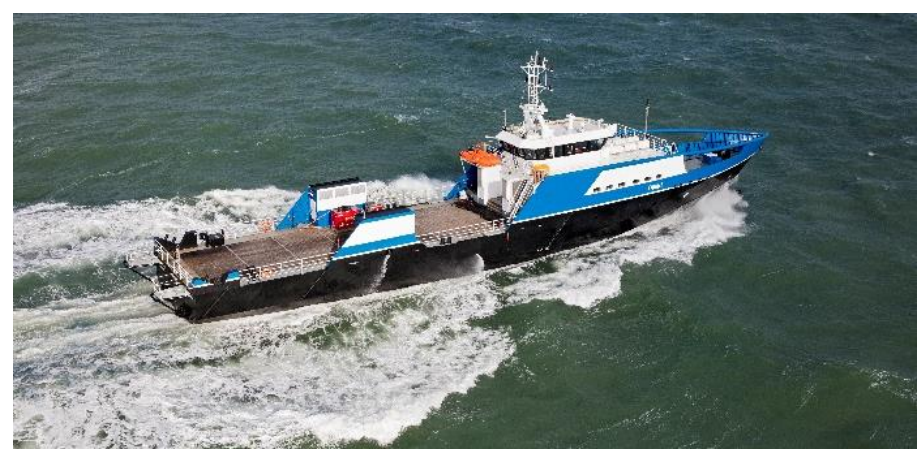

Fig. 8. Fast Supply Vessel Karina 


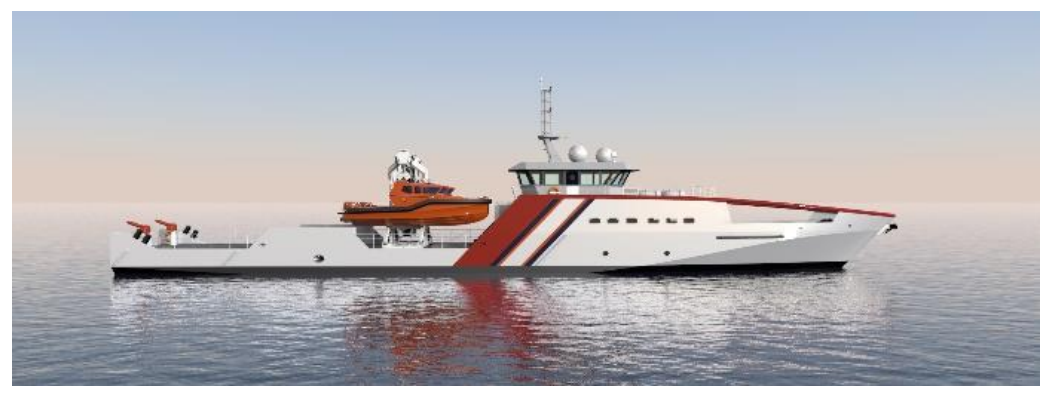

Fig. 9. Same vessel in OPV execution

In 2014, sea trials were carried out on delivery of the MV Karina, a 55 m/210 ton deadweight Fast Supply Vessel from Shipyard De Hoop. The sea trials were conducted in exactly the same conditions with and without Hull Vane ${ }^{\circledR}$ and the shaft power was measured during the official speed trials. These showed a power reduction from $10 \%$ at 12 knots (idling speed, Froude number 0.26 ) which gradually increased to 15\% 21 knots (maximum speed, Froude number 0.47) from the Hull Vane ${ }^{\circledR}$. Visually, the wave profile generated by the ship was clearly less with the Hull Vane ${ }^{\circledR}$.

\section{Patrol Vessel RPA 8 - Port of Rotterdam}

In 2017, model tests were carried out on the new 25 m patrol vessel RPA 8 built by Shipyard Kooiman for the Port of Rotterdam, with and without Hull Vane ${ }^{\circledR}$ at the MARIN towing tank (Netherlands). These model tests showed a power reduction of $25 \%$ at 10.8 knots, $29 \%$ at 14.5 knots and of $21.6 \%$ at 18.9 knots (top speed). The model tests also showed a clear difference in wake and stern wave at all speeds. In Figure 10, this is shown for the cruising speed of $10.8 \mathrm{kn}(20 \mathrm{~km} / \mathrm{h}$, Froude number 0.37 ), which corresponds to a speed-to-length ratio of many corvettes and frigates.

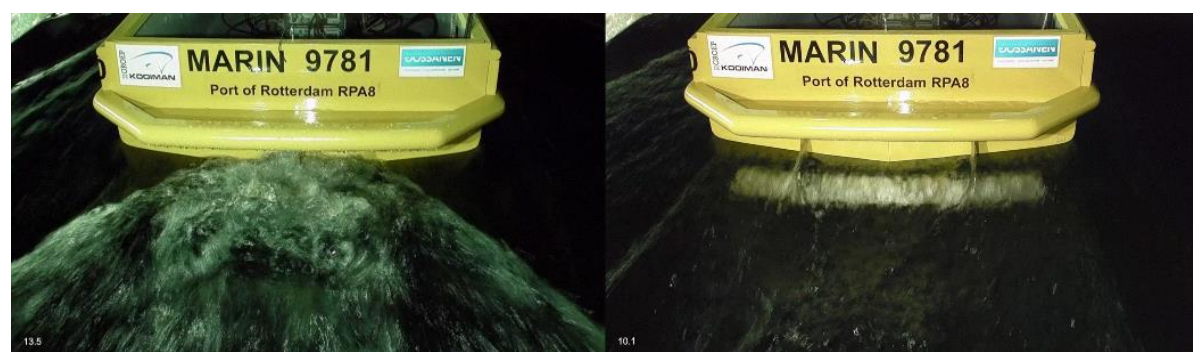

Fig. 10. Comparison of wakes for $25 \mathrm{~m}$ patrol vessel at $11 \mathrm{kn}$ without (left) and with Hull Vane ${ }^{\circledR}$ (right) [6] 


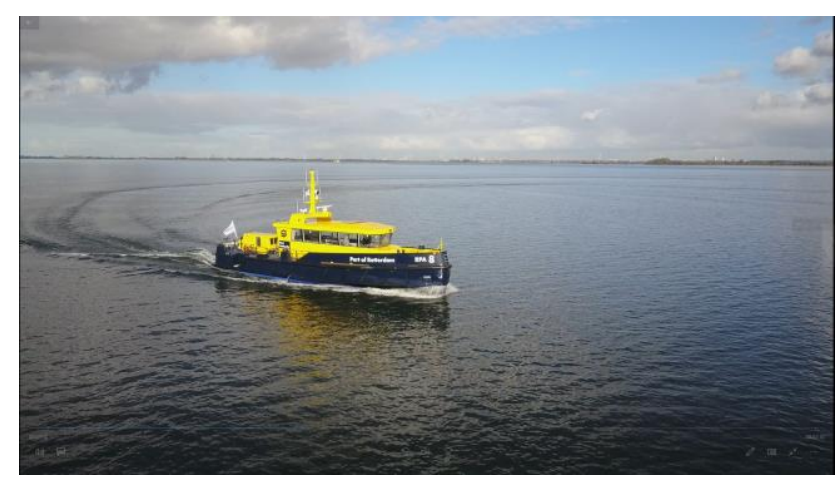

Fig. 11. RPA 8 has exceptionally low wavemaking properties and high efficiency [7]

\section{AMECRC series - generic fast displacement hull form [4]}

An extensive CFD study was done to compare the performance of the Hull Vane ${ }^{\circledR}$ with that of commonly used trim-correction devices such as interceptors and trim wedges on a $50 \mathrm{~m}$ OPV of the AMECRC series (hull form depicted below). The hull was analysed at speeds ranging from 8.6 knots (Fn 0.2) to 34.4 knots (Fn 0.8).

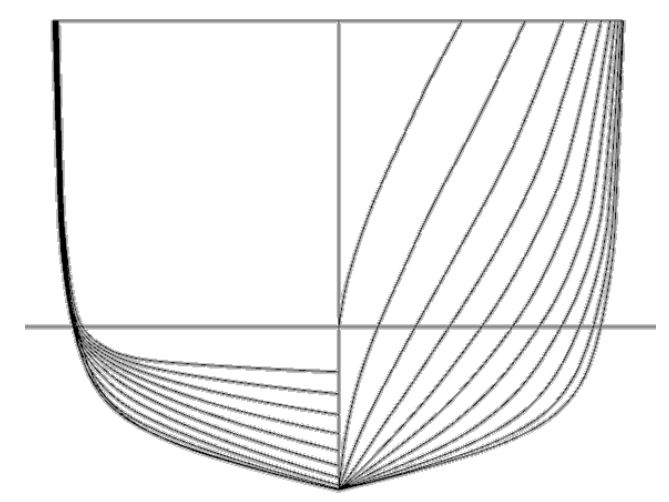

Fig. 12. Linesplan of AMECRC series 13 [4]

The results are summarised in the graph below, plotting the resistance of each 'challenger' relative to the resistance of the bare hull at each speed. Two conclusions are immediately visible: for this hull, it is needed to apply a trim correction device or the resistance at top speed will be $10 \%$ higher. All trim correction devices perform roughly equal at speeds above 30 knots (Fn $>0.7$ ). Secondly, at speeds between 10 and 30 knots Fn (0.2-0.6), the Hull Vane ${ }^{\circledR}$ outperforms the second-best solution by up to $25 \%$, showing a huge saving potential, especially given that patrol vessel usually sail at a modest cruising speed $(12-15 \mathrm{kn})$. It is also noted that many 
naval and coastguard vessels have their design speed in the most beneficial range (Fn 0.3-0.5). While this study is specific for this hull form, the results are typical for the studies carried out on about 200 ships so far.

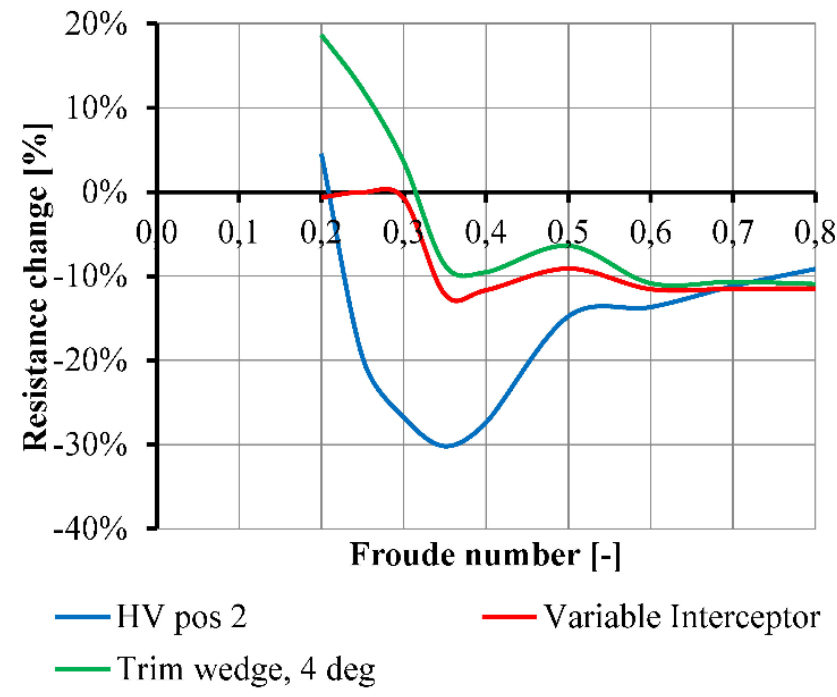

Fig. 13. Resistance comparison Hull Vane, trim wedge, interceptor [4]

\section{Damen Shipyards $61 \mathrm{~m} \mathrm{OPV} \mathrm{[2]}$}

A similar CFD study was done to compare the performance of the Hull Vane ${ }^{\circledR}$ with that of the trim wedge applied as standard on a new design of Damen Shipyards. In this case, both the appended and integrated Hull Vane® were compared to the benchmark and to a lengthened version of the benchmark, with a lengthover-all longer than that of the ship with appended Hull Vane ${ }^{\circledR}$. The results were presented at the FAST Conference in Nantes in 2017.

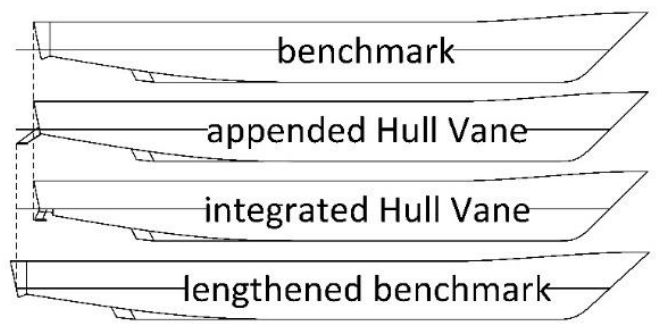

Fig. 14. Four alternatives compared of the same vessel [2] 
The results showed a best performance for the lengthened vessel at the top speed of 26 knots and a break-even at 23.5 knots between the lengthened vessel (with displacement kept constant) and the vessel with appended Hull Vane ${ }^{\circledR}$. At all speeds below 23.5 knots, the vessel with appended Hull Vane ${ }^{\circledR}$ had a significantly lower power requirement (and fuel consumption).

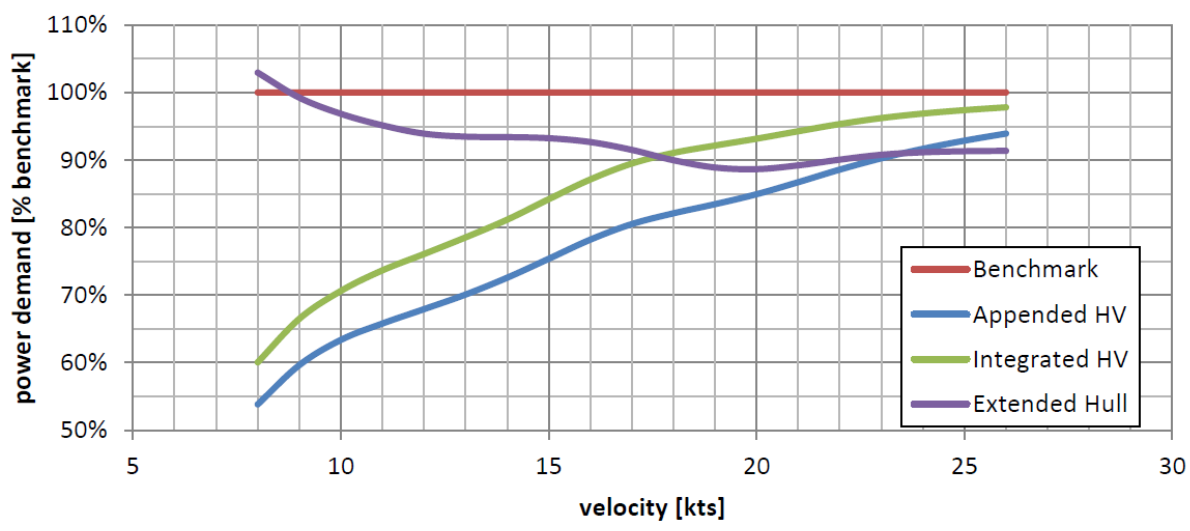

Fig. 15. Relative power/speed graph for 4 variants of Damen 6110 OPV [2]

\section{Holland Class 108 m OPV [1]}

The Holland Class is a series of four Oceangoing Patrol Vessels of the Royal Netherlands Navy. At the FAST Conference in Washington DC in 2015, the results of an extensive CFD study were presented. The study showed resistance reductions of $13.7 \%$ at 12.5 knots, $15.3 \%$ at 17.5 knots and $11.1 \%$ at 22.5 knots. Taking into account the operational profile of the vessel, which includes a lot of slow speed sailing, a Hull Vane ${ }^{\circledR}$ retrofit was estimated to yield a saving on annual fuel consumption (for propulsion) of $12.5 \%$, in addition to a marked improvement in seakeeping.

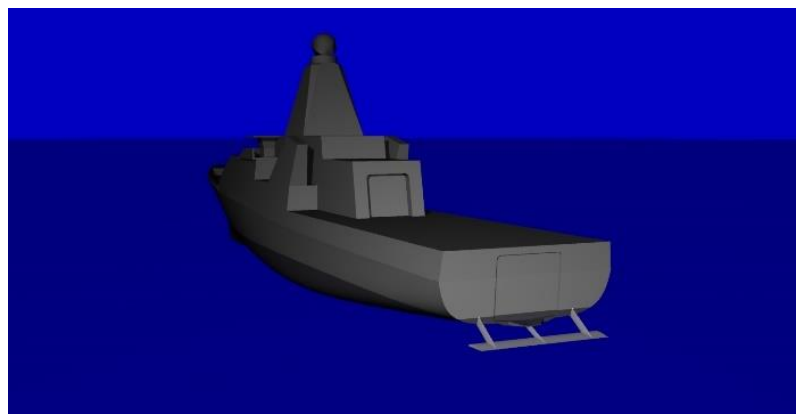

Fig. 16. Proposed Hull Vane ${ }^{\circledR}$ configuration on Holland Class OPV [1] 
The study was followed by a deeper optimisation in 2017, followed by an extensive model testing program at the MARIN towing tank, which confirmed the predicted savings potential. The Dutch navy is now evaluating all results in order to proceed with a retrofit.

\section{DTMB5415 - generic Destroyer hull form [3]}

The DTMB 5415 is a generic hull form of a $142 \mathrm{~m}$ destroyer which was never built, but released by the US Navy (David Taylor Model Basin) for research purposes. A very limited optimisation study for the Hull Vane® was done on this vessel in 2006, and the results were presented at the MAST conference in Amsterdam in 2016.

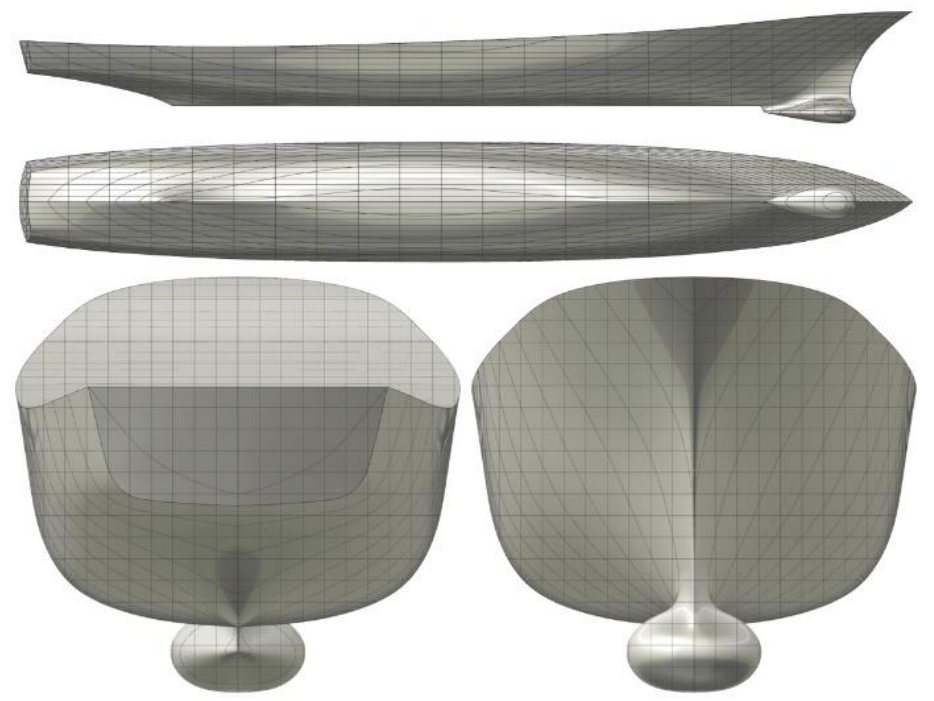

Fig. 17. DTMB5415 hull form [3]

The hull was analysed with and without Hull Vane ${ }^{\circledR}$ at speeds of 18,24 and 30 knots. The resistance reductions found were $7.7 \%$ at 18 knots, $8.4 \%$ at 24 knots and $6.7 \%$ at 30 knots. In all cases, a marked improvement of the stern wave was observed, as shown in the picture below, comparing the wave profile without Hull Vane $^{\circledR}$ (upper half) to the wave profile with Hull Vane ${ }^{\circledR}$ (lower half) at 24 knots. It is expected that with the current know-how and optimisation method, these results can be significantly improved. It is also noted that the DTMB has a very slender aft ship, while modern frigates and destroyers have a wider, fuller aftbody, which is more suitable for a Hull Vane ${ }^{\circledR}$ application. 


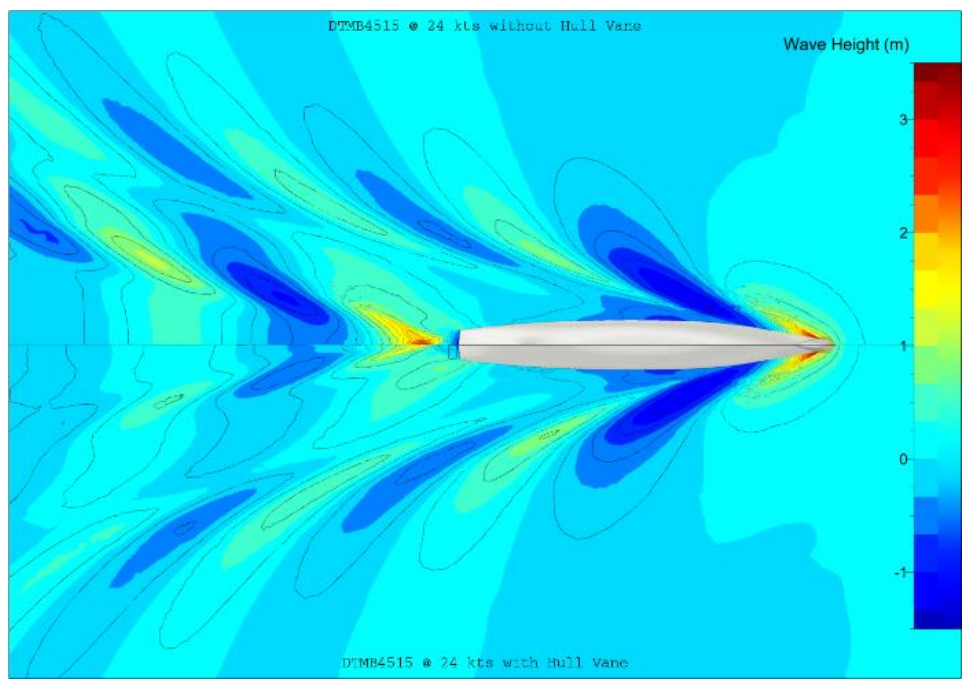

Fig. 18. Wave profile without (upper halve) and with Hull Vane ${ }^{\circledR}$ (lower halve) on DTMB5415 at 24 knots [3]

\section{Other studies}

A large number of other studies have been done, which all indicate the suitability of the Hull Vane ${ }^{\circledR}$ for naval and coastguard ships. Due to the confidential nature of the naval shipbuilding industry, it is usually impossible to publish anything about these studies. One concrete example includes a retrofit of a Hull Vane ${ }^{\circledR}$ which will take place in spring 2018 on an existing Offshore Patrol Vessel.

\section{WHY?}

The most obvious reason to consider a Hull Vane ${ }^{\circledR}$ is energy saving, but the motives can be very different, depending on whether it is an existing ship or a newbuild and whether the client is a shipbuilder or a ship owner. In many cases, the energy saving aspect is a welcome side-effect of a more desirable characteristic. Here are some of the reasons why navies, coastguards and naval shipbuilders and ship designers look at the Hull Vane ${ }^{\circledR}$. Where possible, reference is made to the case studies presented above.

1. Reduced power (newbuild). Reducing the resistance at top speed allows the shipyard to install smaller main engines (or gas turbines) to reach the required top speed. This leads to space saving in the engine room, as not only the main engines 
are smaller, but also the exhaust systems and ventilation systems. The cost saving on the propulsion installation often exceeds the acquisition cost of the Hull Vane ${ }^{\circledR}$, sometimes multiple times. On the RPA 8, the Hull Vane ${ }^{\circledR}$ allowed the use of smaller engines and exhaust systems, which are derived from truck engines, showing cleaner emissions and better performance at partial loads. The vessel has $40 \%$ less installed power than her predecessors (built in 2002) for the same top speed. The generated wave (at $30 \mathrm{~m}$ from centreline) was measured at the same speed and location and showed a 50\% improvement compared to her predecessors.

2. Higher top speed (retrofit). Reducing the resistance at top speed means that with the same propulsion package a higher top speed can be achieved. This is particularly interesting for existing naval ships, which due to hull roughness and added displacement always lose some top speed over time. A Hull Vane ${ }^{\circledR}$ retrofit (e.g. during a midlife upgrade) allows to restore the original top speed, or even improve it in some cases. The top speed of the Holland Class OPVs will increase from 21.5 to over 22 knots.

3. Reduced tank capacity (newbuild). Reducing the resistance at the cruising speed allows to reduce the required tank capacity significantly. This is again a space saving, but also a weight saving, which again is beneficial for the top speed and the overall fuel consumption. Reducing the required payload for fuel can also create reserve capacity for the installation of new systems on board during a midlife upgrade.

4. Increased range (retrofit or newbuild). This is perhaps the most important parameter of all. Range/autonomy gives the naval command more planning freedom and less dependency of fossil fuels. The dependency of fossil fuels (i.e. diesel) can be a liability during scarcity in wartime. Reducing this dependency increases a navy's capabilities. The range of the Holland Class OPVs (specified at 14 knots) will go from 5.000 to 5.850 miles.

5. Higher crossing speed (retrofit or newbuild). The speed of a ship is limited by how fast she can go to cover a certain distance with the limited amount of fuel in her tanks. An example is the Damen 6110 OPV, as shown in the range/speed graph below. When this ship has to make a crossing of 3.500 nautical miles (e.g. sudden hurricane relief work overseas), the crossing speed without Hull Vane ${ }^{\circledR}$ is 11 knots, while with the appended Hull Vane ${ }^{\circledR}$, this increases to 15 knots. This represents a gain in time of $36 \%$ (84 hours / 3.5 days) at a moment when time is crucial. 


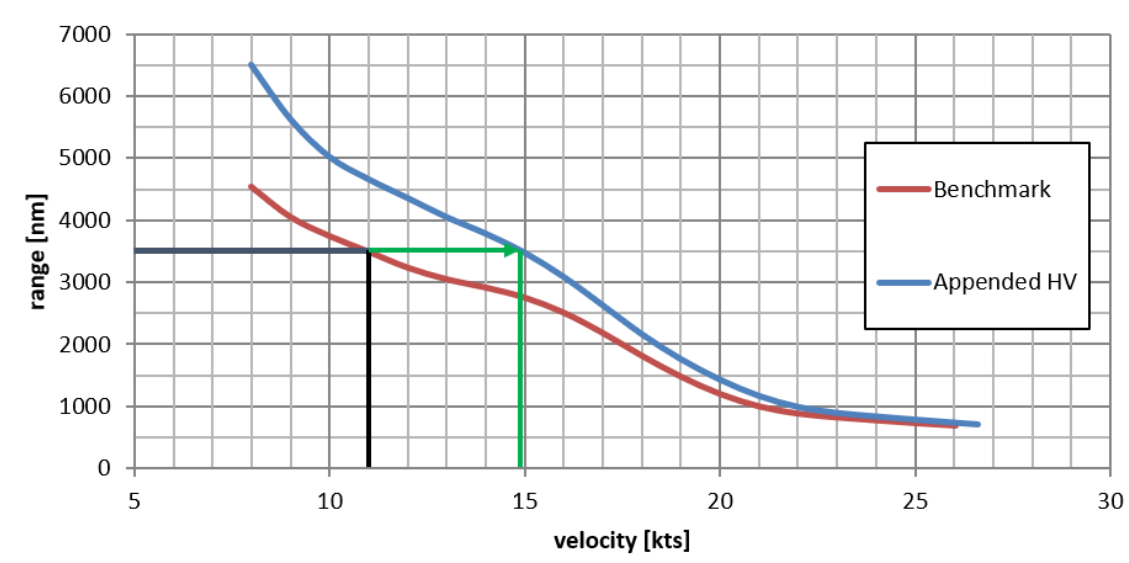

Fig. 19. Range/speed graph for Damen 6110 OPV [2]

6. Higher silent speed (retrofit or newbuild). Modern warships often have a diesel-electric (D.E,) mode at lower speeds and a diesel-direct or gas turbine mode at higher speed. The D.E. mode is preferred as the noise emanated from the ship is a lot less, allowing for better listening to submarines with the ship's own sonar systems. As the power curve is still quite horizontal at this speed, the relative speed gain for a given resistance reduction is a lot higher. A larger area can be covered in the same amount of time with the same ship.

7. Lower lifecycle costs (retrofit or newbuild). Most navies have a limited budget, and the fuel and engine maintenance takes a significant portion of it. By reducing the installed propulsion power (newbuilds) and fuel consumption (retrofit and newbuilds), the lifecycle costs of the platform are significantly reduced, freeing up budget for more useful assets (radars systems, weapons systems or personal) than having to buy more navy diesel. On newbuilds, the Hull Vane ${ }^{\circledR}$ is usually cost-negative. On retrofits, the payback time varies between one and six years, depending of the operational profile of the vessel and the obtained savings percentage.

8. Reduced emissions (retrofit or newbuild). Many navies are under pressure to reduce their $\mathrm{CO}_{2}$ emissions. When ships reduce their speed, more ships are needed to cover the same area, which may be a more costly option. The challenge is to reduce $\mathrm{CO}_{2}$ emissions while maintaining the same operational profile. Any reduction in fuel consumption immediately translates to an equal reduction in emissions of $\mathrm{CO}_{2}$, Nox, SOx and Particulate Matter. The reduction in emissions is often helpful to release the funds needed for a Hull Vane ${ }^{\circledR}$ retrofit, even if a quick calculation of payback period should already be sufficient. On the RPA 8, the $\mathrm{CO}_{2}$ emission reduction from the 2.6 square meter Hull Vane ${ }^{\circledR}$ is equivalent to the $\mathrm{CO}_{2}$ absorbed by more than 8.000 trees. 
9. Signature (retrofit or newbuild). The acoustic signature of a warship has three main sources: the stern wave (turbulence), the propellers (cavitation due to overloading) and the noise emanating from the main engines. The Hull Vane ${ }^{\circledR}$ reduces all three of these main sources of underwater noise. It reduces the stern wave and wake turbulence, it reduces the propeller loading (due to lower ship resistance) and the main engines are running quieter when loaded less. More research is needed to quantify this effect, but it is doubtful such research will be published in the public domain.

10. Wave profile reduction (retrofit or newbuild). The reduction of the generated wave profile was an important factor in the decision to integrate a Hull Vane on the patrol vessel RPA 8, as this vessel sails on inland waters with a lot of traffic. For warships, reducing the stern wave also reduces the likelihood to be stricken by wake-homing torpedoes, which are in use e.g. by the North-Korean navy.

11. Constant running trim (newbuild). Due to the trim correction effect, which already takes place at much lower speeds (Fn 0.3-0.5) than for stern flaps or interceptors, the Hull Vane ${ }^{\circledR}$ takes the typical hump out of the resistance curve. It makes it possible to design a ship with a more constant trim over the entire speed range, which is beneficial for operational reasons.

12. Course keeping (retrofit or newbuild). The struts of the Hull Vane® increase the course stability of the vessel, which also means that in case of a retrofit the manoeuvrability characteristics need to be checked if they are close to the limits. An increase of up to a few percent on turning circle diameter is possible. Furthermore, due to the fact that the deeper part of the Hull Vane generates more lift than the less submerged part, there is less outboard heel in turns. Less yawing means more comfortable sailing (and better radar and weapon system performance) in bow- or sternquartering seas.

13. Improved seakeeping(retrofit or newbuild). The Hull Vane ${ }^{\circledR}$ 's dampening of pitch and yaw motions is particularly beneficial for an aft-deck helicopter platform. The reduction in vertical accelerations reduces the impact upon landing (or broadens the operational envelope), while the yaw damping reduces the sideways movements of the helideck. The Hull Vane is entirely passive (like bilge keels) and does not cause sudden movements like for instance a rudder roll stabilisation system which is sometimes disactivated at the request of helicopter pilots. Example: on the $55 \mathrm{~m}$ Karina, the vertical accelerations on the aft deck $110 \%$ of ship length from stern) are reduced by $20 \%$ when sailing in head waves of $1 \mathrm{~m}$ with a period of 5.7 seconds. 
14. Crew comfort (retrofit or newbuild). The reduction of noise (due to increased efficiency) and the reduction of ship motions makes the voyage less demanding from the crew, so they can focus on the work they have to do. Example: on patrol vessel $R P A$ 8, the noise level in the wheelhouse never exceeds $49 \mathrm{~dB}(\mathrm{~A})$, which is exceptional for this type of vessel ( $25 \mathrm{~m} / 19$ knots top speed).

15. Local content (newbuild): Naval ship design and construction is often lead by political reasons more than technical. The Hull Vane ${ }^{\circledR}$ can in some cases be built in the nation which is owner of the ships. Foreign content (propulsion power) can be converted to local content (basic steel construction of Hull Vane ${ }^{\circledR}$ ) in certain cases.

16. Improvement of existing design (newbuild). Certain navies require the use of an existing platform for their new naval ships, which has been proven at sea for a number of years, in spite of the technology we now have to accurately predict performance beforehand. The Hull Vane ${ }^{\circledR}$ provides an opportunity to improve the performance of an existing design without major modifications. It can also overcome the speed penalty due to an increase in displacement, which is not uncommon when an older design has to carry the latest in armament. While the Hull Vane ${ }^{\circledR}$ is very easy to remove should it not answer the expectations (a crane and a blowtorch are usually enough), none of the installed Hull Vanes has ever been removed.

\section{WHEN?}

For a retrofit on an existing vessel, the Hull Vane ${ }^{\circledR}$ can be installed during a mid-life refit or even during a regular maintenance drydocking. The entire piece is prefabricated and shipped to the shipyard before the vessel arrives, and the installation itself can usually be completed in a matter of days.

For a newbuilding, it's more complicated. To take advantage of all benefits (e.g. cost saving on propulsion installation), it's best to include the Hull Vane ${ }^{\circledR}$ in the design from a very early stage. This also allows for a well-integrated solution, taking into account all possible constraints, such as RIB launchings or towed-array systems.

Several navies are waiting to see the Hull Vane ${ }^{\circledR}$ applied on a naval ship before taking action, but there is not really a reason for this. From a hydrodynamic perspective, there is not all that much difference between a naval ship, a superyacht 
or certain offshore vessels. Technology such as Computational Fluid Dynamics computations, Finite Element Analysis and model testing give a very good indication of the both the performance and the strength of the device. This is evidenced by the installations completed. At the end of the first quarter of 2018, eleven Hull Vanes have been built. The Hull Vanes in operation have all confirmed the savings predictions and have accumulated 33 years of sailing without a single repair, showing that Hull Vane ${ }^{\circledR}$ is proven technology.

\section{HoW?}

At the start of every Hull Vane ${ }^{\circledR}$ project, be it a retrofit or a newbuild, comes a feasibility study. In this study, the Hull Vane ${ }^{\circledR}$ is specifically optimised for the ship in question. The size, shape and position of the Hull Vane ${ }^{\circledR}$ is very dependent of the hull shape and the constraints imposed on each project. CFD computations give an indication of the minimal savings to be expected. Sometimes the optimisation is done for one speed, sometimes for several speeds (e.g. silent speed, transit speed and top speed). Upon completion of the feasibility study, the shape, performance and exact cost of the Hull Vane ${ }^{\circledR}$ are known, and the client can either proceed to have the Hull Vane ${ }^{\circledR}$ built or to go through a second, deeper optimisation phase, possibly followed by model testing or third-party validation through independent CFD computations.

\section{CONCLUSIONS}

While it took thirty years to move on from the first application of a bulbous bow on a ship - coincidentally it was a naval ship - to the second, the development of the Hull Vane ${ }^{\circledR}$ has been much quicker. The results presented in this paper show that the Hull Vane ${ }^{\circledR}$ is a valid proposition to improve the efficiency and capabilities of naval and coastguard vessels. Several naval shipbuilders and navies have picked this up and are proceeding with both research and full scale applications often behind closed doors. The innovation comes at the right time, when fuel prices are on the rise, there is awareness about the risk inherent to dependency of fossil fuels and the pressure to reduce $\mathrm{CO}_{2}$ emissions. At the same time, naval capabilities must not be reduced, but rather increased, and the wellbeing and safety of naval personnel improved where possible. 


\section{REFERENCES}

[1] Bouckaert B., Uithof K., Oossanen P. G. van, Moerke N., Nienhuis B., Bergen J. van, A Life-cycle Cost Analysis of the Application of a Hull Vane to an Offshore Patrol Vessel, FAST Conference 2015, Washington DC, USA, 2015.

[2] Hagemeister N., Uithof K., Bouckaert B., Mikelic A., Hull Vane ${ }^{\circledR}$ versus Lengthening, a comparison between four alternatives for a $61 \mathrm{~m}$ OPV, FAST Conference 2017, Nantes, France, 2017.

[3] Uithof K., Bouckaert B., Moerke N., Oossanen P. G. van, Hull Vane ESD on DTMB5415 DestroyerA CFD Analysis of the Effect on Resistance, MAST Conference 2016, Amsterdam, Netherlands, 2016.

[4] Uithof K., Hagemeister N., Bouckaert B., Oossanen P. G. van, Moerke, N., A systematic comparison of the influence of the Hull Vane ${ }^{\circledR}$, interceptors, trim wedges, and ballasting on the performace of the 50m AMECRC series \#13 patrol vessel, Warship 2016 'Advanced Technologies in Naval Design, Construction, \& Operation', Bath, UK, 2016.

[5] https://www.hullvane.com/tech-talk/ [access 14.04.2018].

[6] https://youtu.be/4CE6zBYTNP0 [access 18.04.2018].

[7] https://youtu.be/BWI38IH7ruE [access 18.04.2018].

\section{PODWODNY SPOILER NA OKRECIE WOJENNYM: DLACZEG O, KIEDY I JAK?}

\section{STRESZCZENIE}

Istnieje wiele urządzeń energooszczędnych dla statków dostępnych na rynku, ale niewiele z nich znalazło szerokie zastosowanie na okrętach wojennych, z jednym wyjątkiem: bulwiastym dziobem. Bulwiasty dziób został opracowany dla okrętów na początku XX wieku i obecnie jest szeroko rozpowszechniony na różnych konstrukcjach statków. Wiele osób zastanawiało się, czy efekt bulwiastego dzioba - zmniejszający opór statku przez zmniejszenie fali dziobowej - mógłby zostać w jakiś sposób zreplikowany na rufie — poprzez zmniejszenie fali rufowej. Dokładnie tak jest to wykonywane przez nowe, opatentowane urządzenie energooszczędne o nazwie Hull Vane ${ }$.

Skonstruowane ono zostało przez holenderskiego hydrodynamika dr. Petera van Oossanena dla jachtu biorącego udział w America's Cup na początku XXI wieku. Badania z ostatnich lat wykazały, że występ w kształcie skrzydła najlepiej sprawdza się na statkach, które łączą stosunkowo dużą wyporność $\mathrm{z}$ wysokim zapotrzebowaniem na maksymalną prędkość - nawet jeśli większość godzin żeglarskich odbywa się z połową maksymalnej prędkości. Przykładami są niektóre jednostki przybrzeżne, superjachty, jednostki patrolowe i okręty marynarki wojennej. Na przybrzeżnych jednostkach patrolowych redukcja oporu z Hull Vane ${ }^{\circledR}$ waha się zwykle od 10 do $20 \%$ w całym zakresie użytecznych prędkości. 
W artykule zostaną opisane zasady działania Hull Vane® w celu lepszego zrozumienia urządzenia. Dokonany będzie przegląd pracy wykonywanej na okrętach i jednostkach straży przybrzeżnej (od 25 do $142 \mathrm{~m}$ ) w oparciu o badania Computational Fluid Dynamics, testy modelowe i aplikacje na pełną skalę. Udzielona zostanie odpowiedź na pytanie „dlaczego?” poprzez wytłumaczenie oddziaływań hydrodynamicznych na udoskonalenia konkretnych zdolności okrętów wojennych: mniejsze zużycie paliwa, większy zasięg, zmniejszone pole magnetyczne, wyższą prędkość maksymalną i udoskonaloną dzielność.

Pytanie „kiedy?” skupi się na tym, czy kadłub Hana Vane® ma być częścią nowej konstrukcji, czy też jest czymś, co należy zmodernizować na istniejącym statku. Na koniec odpowiedź na pytanie „jak?” wyjaśni proces integracji Hull Vane ${ }^{\circledR}$ w nowo budowanym projekcie lub modernizacji $\mathrm{w}$ trakcie zmian w połowie eksploatacyjnego życia istniejącego statku.

\section{Słowa kluczowe:}

hydrodynamika, okręty marynarki wojennej, sprawność , oszczędność energii, dzielność, zdolności.

Article history

Received: $\quad 15.06 .2018$

Reviewed: 05.09 .2018

Revised: $\quad 24.09 .2018$

Accepted: $\quad 25.09 .2018$ 